Paul Farmer's deserved fame as global health expert, medical anthropologist, and advocate for the poor and the marginal centers on his moral commitment to doing good in the world and on the extraordinary influence of his personal call to a generation of young men and women to make the same remarkable commitment. Here are the words, the stories, the passion, the humor, the humanityvulnerable and powerful - that constitute Paul's magic. Here is Paul at those special moments when we want and need a moral exemplar, calling us to do what good we can for those who have nothing, who are broken, who are left behind, who are sick and disabled, who need to be accompanied, and whose betterment betters us. Against the selfishness of the market model and the deadening cynicism of the media, here is straight talk about why, as the song goes, "you've got to serve somebody," why caregiving and doing good really do matter to the world and to each of us.

- ARTHUR KLEINMAN, Esther and Sidney Rabb Professor of Anthropology at Harvard University

Paul Farmer has a knack for persuading an audience to participate in his lectures, whether aloud or in silence. In other words, he never bores his audience. The liveliness of his talks comes in part from his delivery, but also from the qualities of the lectures themselves: the freshness of their ideas, their wit, and their passion. And these, thankfully, are qualities which this collection preserves.

- TRACY KIDDER, Pulitzer Prize-winning author of The Soul of a New Machine, Among Schoolchildren, Mountains Beyond Mountains, and other titles.

Paul Farmer is the most compelling voice for justice in a generation. In this volume are the stories and insights that have helped thousands of students imagine - and fight for-a better world. Read this to be inspired. Read this to learn. Most importantly, when you're done, give this book to a friend and join the movement for health equity.

- JONNY DORSEY, cofounder of FACE AIDS and Global Health Corps 
This collection of speeches brings us close to Paul Farmer in a way that scholarly publications can't. In these pages, I hear Paul's voice clearly: his tenderness, his anger, his passion for justice, the incendiary sense of humor that has regularly doubled me over with laughter for twenty-five years - and often made me worry for Paul's safety, as he aimed his barbs at the uncaring power holders of this world. Paul speaks directly to young people grappling with big decisions: about the values they will live by, the work they will choose, where their responsibility for other people begins and ends. But these questions concern all of us. And, for anyone struggling with these issues, I can't imagine a more challenging yet inspiring guide than Paul Farmer.

-JIM YONG KIM, President of the World Bank Group, former President of Dartmouth College, cofounder of Partners In Health.

The fingerprints of Dr. Paul Farmer are every where in the world. I have seen them firsthand in Haiti, Rwanda, and right here in the United States. Whenever there is a need, Paul is the first guy out the door. After all, curing or repairing the world is ambitious and tough work, but one can't help feeling more optimistic about our fate knowing Dr. Farmer is on the job. In his new book, you get more of an insight into this modern life hero-what makes him tick, his frailties, and what he worries about at night, long after most of the world is asleep. We also learn what inspires him, and the answer may surprise you.

Paul is my friend, and I have long wondered about the answers to some of these questions, yet never had the opportunity to ask. I also know that Paul will be mad at me for calling him a hero. His humility is legendary and one hundred percent genuine. Medical students all over the world have told me they entered our shared profession because of Dr. Paul Farmer. Now, it is time for the rest of the planet to be inspired, and in these pages they learn what it takes To Repair the World.

- SANJAY GUPTA, Chief Medical Correspondent at CNN and Professor of Neurosurgery at Emory University School of Medicine 
To Repair the World 
The publisher gratefully acknowledges the generous support of the Anne G. Lipow Endowment Fund for Social Fustice and Human Rights of the University of California Press Foundation, which was established by Stephen M. Silberstein 


\title{
To Repair the World
}

\author{
Paul Farmer \\ Speaks to the Next Generation
}

\author{
Edited by Jonathan Weigel
}

With a foreword by President Bill Clinton

\section{甲}

UNIVERSITY OF CALIFORNIA PRESS

Berkeley Los Angeles London 
University of California Press, one of the most distinguished university presses in the United States, enriches lives around the world by advancing scholarship in the humanities, social sciences, and natural sciences. Its activities are supported by the UC Press Foundation and by philanthropic contributions from individuals and institutions. For more information, visit www.ucpress.edu.

University of California Press

Berkeley and Los Angeles, California

University of California Press, Ltd.

London, England

(C) 2013 by The Regents of the University of California

Library of Congress Cataloging-in-Publication Data

Farmer, Paul, 1959-

[Speeches. Selections]

To repair the world : Paul Farmer speaks to the next generation /

edited by

Jonathan Weigel ; foreword by President Bill Clinton.

pages $\mathrm{cm}$

ISBN 978-0-520-27597-3 (hardback)

I. Public health-Social aspects. 2. Public welfare. 3. Public

health administration. 4. Public health-Citizen participation.

5. Public health-Addresses I. Weigel, Jonathan, I986- II. Title.

RA4I8.F36 2013

$362 . \mathrm{I}-\mathrm{dc} 23$

2013002004

Manufactured in the United States

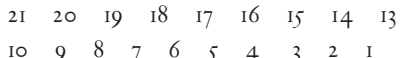

In keeping with a commitment to support environmentally responsible and sustainable printing practices, UC Press has printed this book on Natures Natural, a fiber that contains $30 \%$ post-consumer waste and meets the minimum requirements of ANSI/NISO Z39.48-I992 (R I997)

(Permanence of Paper). 
To Fennie Block, with deep gratitude

for her accompaniment over the years

P.F. 


\section{CALIFORNIA SERIES}

IN PUBLIC ANTHROPOLOGY

The California Series in Public Anthropology

emphasizes the anthropologist's role as an engaged intellectual. It continues anthropology's commitment to being an ethnographic witness, to describing, in human terms, how life is lived beyond the borders of many readers' experiences. But it also adds a commitment, through ethnography, to reframing the terms of public debate-transforming received, accepted understandings of social issues with new insights, new framings.

Series Editor:

Robert Borofsky (Hawaii Pacific University)

Contributing Editors:

Philippe Bourgois (University of Pennsylvania), Paul Farmer (Partners In Health), Alex Hinton (Rutgers University),

Carolyn Nordstrom (University of Notre Dame), and Nancy Scheper-Hughes (UC Berkeley)

University of California Press Editor: Naomi Schneider

Volume 29. To Repair the World: Paul Farmer Speaks to the Next Generation 